\title{
Characterization and Sintering of MgO-Doped $\beta$-Alumina Powders Prepared by the Hydrolysis of Metal Alkoxides
}

\author{
Yoshihiro HIRATA, Shinn-Yih LEE, Kinji SHIMADA and Yoshimi ISHIHARA \\ (Department of Applied Chemistry, Faculty of Engineering, Kagoshima University, ) \\ 1-21-40, Korimoto, Kagoshima-shi 890
}

金属アルコキシドの加水分解で合成された $\mathrm{MgO}$ 添加 $\beta$ アルミナ粒子の性質と焼結

平田好洋・李 信義・島田欣二・石原義巳

(鹿児島大学工学部応用化学科, 890 鹿児島市郡元 1-21-40)

\begin{abstract}
Platelike $\beta$-alumina particles with an average size of $0.3 \mu \mathrm{m}$ were formed at $1100^{\circ} \mathrm{C}$ from alkoxide-derived amorphous powder with the chemical composition (wt\%) $9.3 \mathrm{Na}_{2} \mathrm{O}, 1.0 \mathrm{MgO}$, and balance $\mathrm{Al}_{2} \mathrm{O}_{3}$. No $\beta^{\prime \prime}$-alumina formed from the gel of mixed alkoxides. The particle size of the $\beta$-alumina increased with increasing $\mathrm{MgO}$ content. Aggregation of the platelike particles in green compacts caused a tendency toward the formation of pores surrounded by flat planes, and pores of this type remained in the sintered samples. Densification of the $\beta$-alumina powders was inhibited by $\mathrm{MgO}$, and $\mathrm{Al}_{2} \mathrm{O}_{3}$ dissociated from the $\beta$-alumina during sintering in an $\mathrm{Na}_{2} \mathrm{O}$-poor atmosphere. The $\mathrm{Na}_{2} \mathrm{O}$ loss from green compacts in a semi-closed $\mathrm{Pt}$ container reached a constant value after a short sintering time and was suppressed in an $\mathrm{Na}_{2} \mathrm{O}$-rich atmosphere. In addition, the evaporation behavior of $\mathrm{MgO}$, measured during sintering at $1600^{\circ} \mathrm{C}$, followed Henry's law in the $\mathrm{MgO}-\mathrm{Al}_{2} \mathrm{O}_{3}$ system of $\beta$-alumina.

[Received January 16, 1990 ; Accepted March 12, 1990]
\end{abstract}

Key-words : MgO-doped $\beta$-alumina, Alkoxide, Hydrolysis, Platelike particle, Densification, Pore

\section{Introduction}

Metal alkoxides have great potential as ceramic precursors, giving ceramic powders with high purity, fine size, and narrow particle size distribution. ${ }^{1)-4}$ ) Most of the alkoxides react with water at low temperatures to form hydroxides or oxides. The physicochemical properties of the resultant oxide or hydroxide powders are affected by the hydrolysis rate of the alkoxides (temperature and catalyst) ${ }^{5), 6)}$ and the molar ratio of alkoxide to water. ${ }^{7), 8)}$ Powder preparation through the use of alkoxides is especially effective for achieving high chemical homogeneity among particles in multicomponent systems. ${ }^{9-11)}$ In this method, uniformly small amounts of one metal source can be mixed easily with large amounts of a second metal source in the same atomic-length range.

The present study applies the alkoxide method to the preparation of $\beta$-alumina powders and investigates the physicochemical properties and sintering behavior of the derived $\beta$-alumina powders. Beta alumina with an ideal composition $\mathrm{Na}_{2} \mathrm{O} \cdot 11 \mathrm{Al}_{2} \mathrm{O}_{3}$ is well known as an efficient sodium-ion conductor that can be used as the solid electrolyte of an $\mathrm{Na}-\mathrm{S}$ battery. ${ }^{12)-19)}$ Previous attempts at sol-gel formation of $\beta$-alumina were reported by Tseng et al. ${ }^{20)}$ and Yoldas and Partlow. ${ }^{21)}$ In the present study, mixtures of $\mathrm{NaOC}_{2} \mathrm{H}_{5}, \mathrm{Al}\left(\mathrm{O}-i-\mathrm{C}_{3} \mathrm{H}_{7}\right)_{3}$, and $\mathrm{Mg}\left(\mathrm{OC}_{2} \mathrm{H}_{5}\right)_{2}$ in a refluxed benzene-ethyl alcohol solution were hydrolyzed solwly with water diluted with ethyl alcohol. Changes in phase, chemical composition, and particle size caued by heating the as-produced $\beta$-alumina powders were analyzed, and the sintering behavior of the heat-treated powders was studied at temperatures up to $1600^{\circ} \mathrm{C}$.

\section{Experimental procedure}

\section{1 Hydrolysis of mixed alkoxides}

Three powders, with the chemical compositions shown in Table 1, were prepared by the hydrolysis of mixed alkoxides of $\mathrm{NaOC}_{2} \mathrm{H}_{5}, \mathrm{Al}$ $\left(\mathrm{O}-i-\mathrm{C}_{3} \mathrm{H}_{7}\right)_{3}$, and $\mathrm{Mg}\left(\mathrm{OC}_{2} \mathrm{H}_{5}\right)_{2}$. The alkoxides (32 to $35 \mathrm{~g}$ of $\mathrm{Al}\left(\mathrm{O}-i-\mathrm{C}_{3} \mathrm{H}_{7}\right)_{3}$ (>99 wt\%), 2.1 to $2.3 \mathrm{~g}$ of $\mathrm{NaOC}_{2} \mathrm{H}_{5}(98.6 \mathrm{wt} \%)$, and 0.6 to $2.8 \mathrm{~g}$ of $\left.\mathrm{Mg}\left(\mathrm{OC}_{2} \mathrm{H}_{5}\right)_{2}(99.9 \mathrm{wt} \%)\right)$ were dissolved at room temperature into $250 \mathrm{ml}$ of benzene $(99.5 \mathrm{wt} \%)$ and 100 and $50 \mathrm{ml}$ of ethyl alcohol $(99.5 \mathrm{wt} \%)$, 
Table 1. Chemical composition of as-produced powders from mixed alkoxides.

\begin{tabular}{|c|c|c|c|}
\hline Powder & $\mathrm{Na}_{2} \mathrm{O}(\mathrm{wt} \%)$ & $\mathrm{MgO}(\mathrm{wt} \%)$ & $\mathrm{Al}_{2} \mathrm{O}_{3}(\mathrm{wt} \%)$ \\
\hline \multirow[t]{2}{*}{ A } & 9.34 & 0.99 & 89.67 \\
\hline & $\left(\mathrm{Na}_{2} \mathrm{O} \quad 0.163 \mathrm{MgO}\right.$ & $\left.5.83 \mathrm{Al}_{2} \mathrm{O}_{3}\right)^{*}$ & \\
\hline \multirow[t]{2}{*}{ B } & 9.74 & 2.05 & 88.22 \\
\hline & $\left(\mathrm{Na}_{2} \mathrm{O} \quad 0.324 \mathrm{MgO}\right.$ & $\left.5.51 \mathrm{Al}_{2} \mathrm{O}_{3}\right)^{*}$ & \\
\hline C & 6.52 & 3.29 & 90.19 \\
\hline & $\left(\mathrm{Na}_{2} \mathrm{O} \quad 0.776 \mathrm{MgO}\right.$ & $\left.8.41 \mathrm{Al}_{2} \mathrm{O}_{3}\right)^{*}$ & \\
\hline
\end{tabular}

respectively. These nonaqueous alkoxide solutions were stirred in a $500 \mathrm{ml}$ flask and then refluxed at $70^{\circ}$ to $72^{\circ} \mathrm{C}$ for $4 \mathrm{~h}$ under a $200 \mathrm{ml} / \mathrm{min}$ flow of dried $\mathrm{N}_{2}$ to ensure mixing. After $4 \mathrm{~h}$ of reflux, enough distilled water $(\approx 11.4 \mathrm{~g}, \mathrm{pH} 5)$ to cause the formation of hydroxides was diluted with $90 \mathrm{ml}$ of ethyl alcohol and added to the refluxed benzene-ethyl alcohol solution at a rate of $2 \mathrm{ml} / \mathrm{min}$. The reflux was continued for $4 \mathrm{~h}$ to complete the hydrolysis of the mixed alkoxides. The as-produced powders in the flask then were removed from the solution, by evaporating the solvent on a hot plate at $188^{\circ} \mathrm{C}$, and heat-treated in a covered $\mathrm{Pt}$ container at $1000^{\circ}$ to $1400^{\circ} \mathrm{C}$ for $3 \mathrm{~h}$ in air. Phases in the as-produced and heat-treated powders were identified by X-ray diffraction ( $\mathrm{Cu} K \alpha$, Model No.2013, Rigaku Corp., Tokyo, Japan) at a scanning rate of $2^{\circ} / \mathrm{min}$. The chemical compositions of the powders were examined by X-ray fluorescence (Rh) at $50 \mathrm{kV}$ (System 3080-E, Rigaku Corp., Tokyo, Japan). About $300 \mathrm{mg}$ of the powders were mixed with $3 \mathrm{~g}$ of $\mathrm{Li}_{2} \mathrm{~B}_{4} \mathrm{O}_{7}$ and the mixture melted to form 35-mm-diameter glass spheres, which were chemically analyzed for $\mathrm{Na}, \mathrm{Al}$ and $\mathrm{Mg}$ content. The shape and structure of the particles were observed by transmission electron microscopy at $200 \mathrm{kV}$ (H-700 H Type, Hitachi Ltd., Tokyo, Japan). The as-produced and heat-treated powders were then ultrasonically dispersed in water, settled onto a colloidal membrane (amyl acetate), and finally coated with sputtered carbon for TEM observation. The powders were also examined by scanning electron microscopy at $75 \mathrm{kV}$.

\section{2 Sintering of $\mathrm{MgO}$-doped $\beta$-alumina pow- ders}

The heat-treated powders were compacted into disks 9 to $10 \mathrm{~mm}$ in diameter and 2 to $3 \mathrm{~mm}$ thick by isostatic pressing at $294 \mathrm{MPa}$ after preliminary uniaxial pressing at $37 \mathrm{MPa}$. Green densities were calculated from measured dimensions $( \pm 0.01 \mathrm{~mm})$ and compact weight. These green compacts were embedded into the as-produced powders in a covered $\mathrm{Pt}$ container ( 15 by 13 by $8 \mathrm{~mm}$ ) and heated in air at $5^{\circ} \mathrm{C} / \mathrm{min}$ to above $1500^{\circ} \mathrm{C}$. Bulk densities after sintering for 10 to 120 min were measured by the Archimedes method using distilled water. The relative densities of the green and sintered samples for series A, B and C (Table 1) were calculated from the true densities 3. $46,3.45$, and $3.41 \mathrm{~g} / \mathrm{cm}^{3}$ of $\mathrm{MgO}$-doped $\beta$ alumina powders with the chemical compositions $\mathrm{Na}_{2} \mathrm{O} \cdot 0.189 \mathrm{MgO} \cdot 6.23 \mathrm{Al}_{2} \mathrm{O}_{3}, \mathrm{Na}_{2} \mathrm{O} \cdot 0.315 \mathrm{MgO}$. $5.72 \mathrm{Al}_{2} \mathrm{O}_{3}$, and $\mathrm{Na}_{2} \mathrm{O} \cdot 0.817 \mathrm{MgO} \cdot 9.02 \mathrm{Al}_{2} \mathrm{O}_{3}$, respectively, that were formed by heat treatment at $1200^{\circ} \mathrm{C}$ for $3 \mathrm{~h}$. The phases and chemical compositions of the sintered samples were investigated as described previously (see Section (2.1)). The samples were next polished and etched at $70^{\circ} \mathrm{C}$ for 10 to $120 \mathrm{~s}$ by a $17 \% \mathrm{H}_{3} \mathrm{PO}_{4}$ aqueous solution; the microstructures were observed by SEM.

\section{Results}

\subsection{Phases and chemical compositions of heat-treated powders}

All as-produced powders with the chemical compositions shown in Table 1 were amorphous under X-ray diffraction. Figure 1 shows the phase change of powder $A$ with heating. The asproduced powders changed to mixtures of $\beta$ alumina, $\gamma$-alumina, and mullite-type alumina at $1000^{\circ} \mathrm{C}$, and no phase but that of $\beta$-alumina formed above $1100^{\circ} \mathrm{C}$. It has been reported ${ }^{22)-24)}$ that mullite-type alumina ( $\mathrm{i}$ ) is a metastable phase that appears in powders prepared through gelation from an aqueous solution containing $\mathrm{Na}$ and $\mathrm{Al}$ and (ii) forms from $\gamma$-alumina and $\mathrm{Na}$ adsorbed onto the defect spinel structure and decomposes to $\beta$-alumina at high temperature ( $1200^{\circ} \mathrm{C}$ ). As shown in Fig. 1, phase relations for

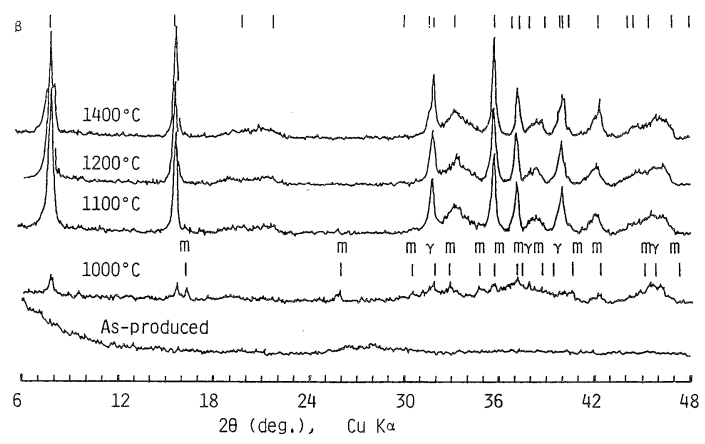

Fig. 1. Phase change with heating of the as-produced powder A with the composition shown in Table 1. The $\beta, \gamma$ and $m$ mean $\beta$-alumina, $\gamma$-alumina and mullite type alumina, respectively. 

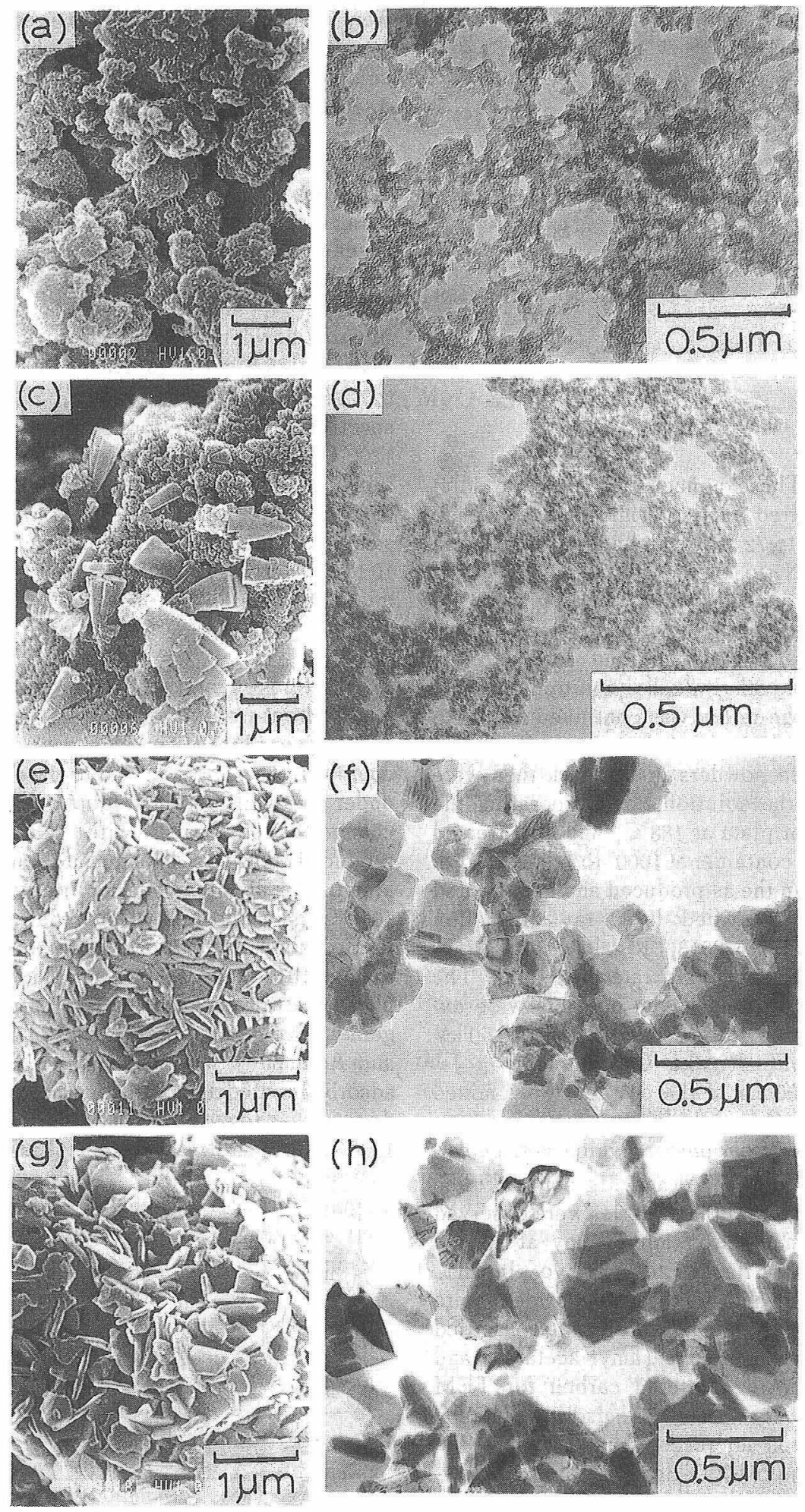

Fig. 2. SEM and TEM pictures of the as-produced powder $\mathrm{A}(\mathrm{a}, \mathrm{b})$ and powders heat-treated at $1000^{\circ} \mathrm{C}$ $(c, d), 1100^{\circ} \mathrm{C}(e, f)$ and $1400^{\circ} \mathrm{C}(\mathrm{g}, \mathrm{h})$. 

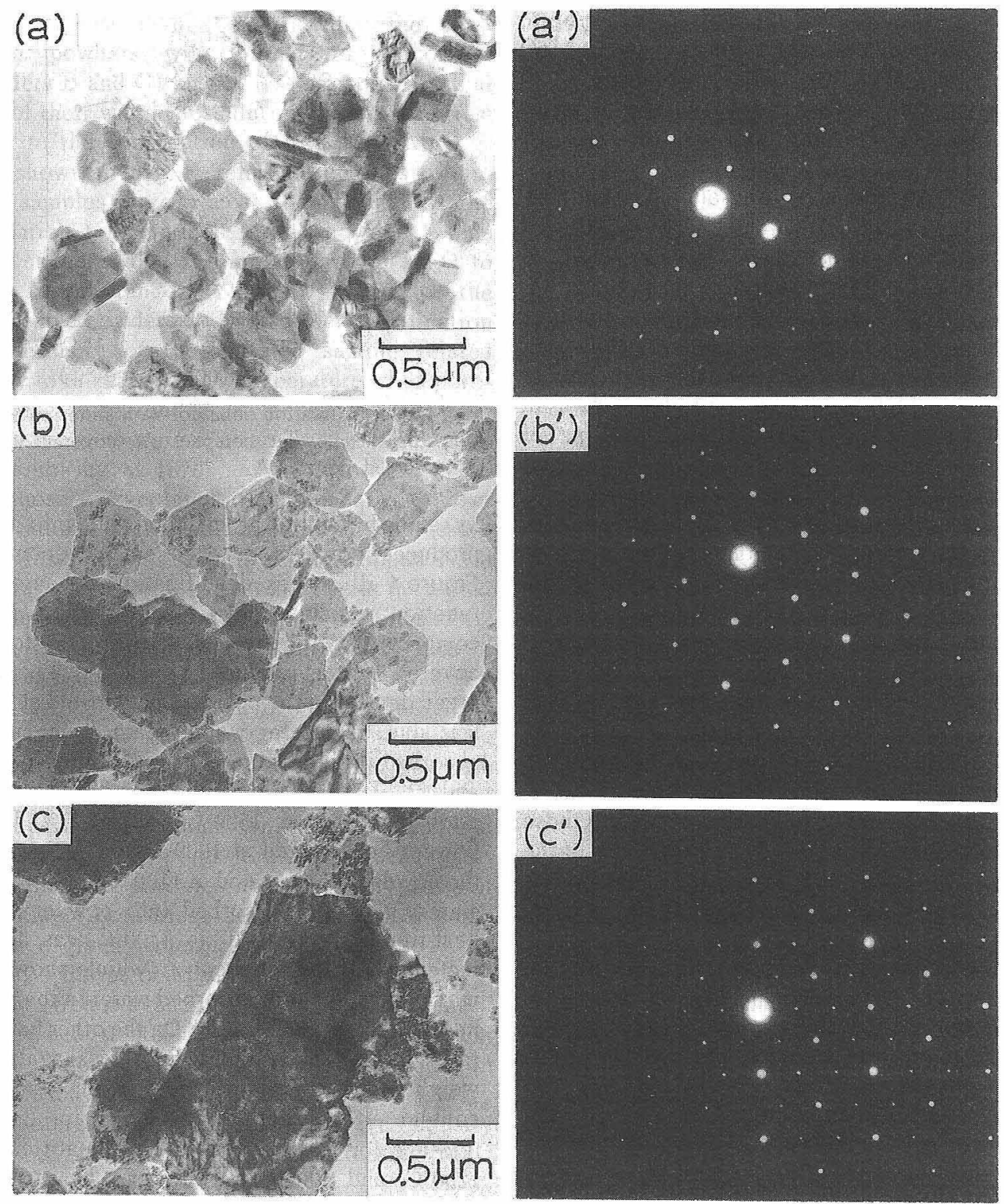

Fig. 3. TEM pictures and electron diffraction patterns of the powders $A\left(a, a^{\prime}\right), B\left(b, b^{\prime}\right)$ and $C\left(c, c^{\prime}\right)$ heat-treated at $1200^{\circ} \mathrm{C}$.

the powders heat-treated at $1000^{\circ} \mathrm{C}$ and thermal stability of the mullite-type alumina and $\gamma$ alumina were in accordance with findings from previous studies, ${ }^{22)-24)}$ When powders $\mathrm{B}$ and $\mathrm{C}$ were heat-treated at $1200^{\circ} \mathrm{C}$, only $\beta$-alumina formed. Ritter and Frase ${ }^{25)}$ reported that at $1100^{\circ} \mathrm{C}$ alkoxide-derived powders in the system $\mathrm{Na}_{2} \mathrm{O}-$ $\mathrm{MgO}-\mathrm{Al}_{2} \mathrm{O}_{3}$ with $\beta^{\prime \prime}$-alumina compositions yield a "distorted solid solution of $\beta$-type structure" that is not produced by a solid state reaction and that $\mathrm{Mg}$ substitution in the $\mathrm{Al}-\mathrm{O}$ layers is ordered in the $\beta^{\prime \prime}$ structure but random in the solid solution $\beta$ structure. No $\beta^{\prime \prime}$-alumina formed in heat-treated powders $A, B$, and $C$, in agreement with observations by Ritter and Frase ${ }^{25)}$ and Hodge. ${ }^{24)}$ The molecular mixing of $\mathrm{Na}, \mathrm{Al}$, and $\mathrm{Mg}$ through alkoxide media tends to produce the $\beta$ structure rather than the $\beta^{\prime \prime}$ structure. The actual density (3. 41 to $3.46 \mathrm{~g} / \mathrm{cm}^{3}$ ) of $\beta$-alumina particles formed at $1200^{\circ} \mathrm{C}$ was higher than the reported value $\left(3.24 \mathrm{~g} / \mathrm{cm}^{3}\right)^{26}$ for $\beta$-alumina without $\mathrm{MgO}$; this higher density may be related to the distorted solid solution $\beta$ structure.

Changes in the chemical composition of the as-produced powders ( $A, B$, and $C)$ with heating were examined by $\mathrm{X}$-ray fluorescence. The molar 
ratio of $\mathrm{MgO}$ to $\mathrm{Al}_{2} \mathrm{O}_{3}$ was nearly constant up to $1400^{\circ} \mathrm{C}$. At higher temperatures, however, $\mathrm{MgO}$ evaporation was detected, as described in detail in section (3.4). The evaporation of $\mathrm{Na}_{2} \mathrm{O}$ occurred above $1000^{\circ} \mathrm{C}$, and 3.7 to $6.7 \%$ of the $\mathrm{Na}_{2} \mathrm{O}$ was lost at $1200^{\circ} \mathrm{C}$.

3. 2 Shape and size of $\beta$-alumina particles

Figure 2 shows SEM and TEM photos of as-produced and heat-treated powder A. Asproduced amorphous powders consisting of submicrometer-sized agglomerates shown in Fig. 2 (a) changed to platelike $\beta$-alumina with an average particle size of $0.3 \mu \mathrm{m}$ after heat-treatment at $1100^{\circ}$ to $1400^{\circ} \mathrm{C}$. Those particles shown in Figs. 2(f) and (h) provided spot patterns of electron diffraction, indicating single crystal $\beta$-alumina. In addition, the $\beta$-alumina particles experienced little grain growth in the temperature range of $1100^{\circ}$ to $1400^{\circ} \mathrm{C}$. In the powders heated at $1000^{\circ} \mathrm{C}$, wedge-type crystals that formed in the spherical agglomerate powders of $\gamma$-alumina appeared to be mullite-type alumina. Figure 3 shows the compositional dependence of shape and structure for $\beta$-alumina particles produced at $1200^{\circ} \mathrm{C}$. Powders B and $\mathrm{C}$ revealed fine particles (smaller than about $0.08 \mu \mathrm{m}$ ), in addition to platelike $\beta$-alumina; the electron diffraction patterns of the single crystals corresponded to those of the platelike particles. The average size of the platelike $\beta$-alumina particles in powder $\mathrm{B}$ was $0.6 \mu \mathrm{m}$, larger than that in powder $A$; the particle size of the $\beta$-alumina thus increased with increasing $\mathrm{MgO}$ content. Powder $\mathrm{C}$, with the highest $\mathrm{MgO}$ content, contained the highest concentration of fine particles.

3. 3 Sintering of alkoxide-derived $\beta$-alumina powders

\subsection{Effect of calcination temperature}

Green compacts of heat-treated powders A, B, and $\mathrm{C}$ were sintered in an $\mathrm{Na}_{2} \mathrm{O}$-rich atmosphere

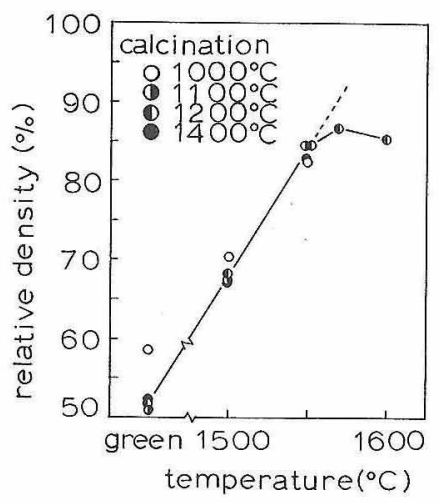

Fig. 4. Densification behavior with sintering temperature for the powder compact A, covered with the as-produced powder A.

by embedding the green compacts into the as produced powders in a covered $\mathrm{Pt}$ container. Figure 4 illustrates densification behavior as a function of sintering temperature for powder compact $A$, with green densities of 51 to $59 \%$, covered with as-produced powder $\mathrm{A}$. The higher green density of the powder heat-treated at $1000^{\circ} \mathrm{C}$ was due to greater weight gain from moisture absorbed into the mixed phases ( $\gamma$, mullite-type, and $\beta$ ). That is, the weight loss of the compacts after sintering at $1500^{\circ} \mathrm{C}$ was $13.6 \%$ for the powder heat-treated at $1000^{\circ} \mathrm{C}$ and $4.1-5.8 \%$ for the powders heat-treated at $1100^{\circ}$ to $1400^{\circ} \mathrm{C}$ before sintering. Water absorbed into powder $\mathrm{A}$ after heat-treatment at $1000^{\circ}$ to $1400^{\circ} \mathrm{C}$ was also detected by IR spectroscopy, which showed the maximum amount of absorbed water in the powder heat treated at $1000^{\circ} \mathrm{C} .{ }^{27), 28)} \mathrm{On}$ the other hand, the ratios of the measured weight loss against the weight loss calculated from $\mathrm{Na}_{2} \mathrm{O}$ and $\mathrm{MgO}$ content after sintering at $1600^{\circ} \mathrm{C}$ for $2 \mathrm{~h}$ were $0.7-1.2$ for powders $B$ and $C$ heat-treated at $1200^{\circ} \mathrm{C}$, and $1.8-3.2$ for powder $\mathrm{A}$ heat-treated at
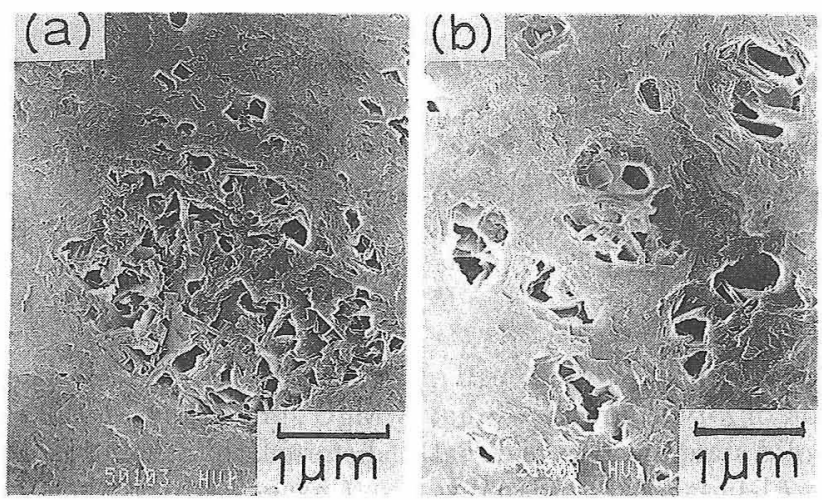

Fig. 5. Microstructures of $\beta$-alumina sintered at $1600^{\circ} \mathrm{C}$ for $20 \mathrm{~min}$ (a) and $120 \mathrm{~min}$ (b) from the powder A calcined at $1200^{\circ} \mathrm{C}$. 
$1200^{\circ} \mathrm{C}$. These results suggest that the heattreated powders with higher $\mathrm{MgO}$ content (powders B and C) absorb less moisture, so that most of their weight loss during sintering corresponds to the evaporation of $\mathrm{Na}_{2} \mathrm{O}$ and $\mathrm{MgO}$.

As shown in Fig. 4, relative densities of sintered samples were almost independent of the calcination temperatures of the powders. This result suggests that the molar ratio of $\mathrm{Na}_{2} \mathrm{O}$ to $\mathrm{Al}_{2} \mathrm{O}_{3}$ in the range $1: 5.6$ to $1: 7.0$ for the heat-treated powders does not affect densification rate. Density of the sintered sample related closely to the calcination temperature when particle shape, size, and green density of the heattreated powders were similar (Fig. 2). Densities after sintering at $1570^{\circ}$ and $1600^{\circ} \mathrm{C}$ were lower than those extrapolated from the data at lower temperatures. Increased density from suppressing $\mathrm{Na}_{2} \mathrm{O}$ loss during sintering was expected for sintering times below $2 \mathrm{~h}$ at $1600^{\circ} \mathrm{C}$, but the actual experimental results showed a small increase of 2 to $3 \%$ in relative density after 10 to $40 \mathrm{~min}$ of sintering. The microstructures of $\beta$-alumina sintered at $1600^{\circ} \mathrm{C}$ are shown in Fig. 5. The SEM photos seem to indicate that the low relative density $(<90 \%)$ is mainly due to the aggregation of platelike particles, forming pores surrounded by flat planes, and which could not be eliminated by sintering. The pores formed between nonoriented platelike particles would be more difficult to eliminate than those between spherical particles at a given sintering temperature.

\subsubsection{Effect of $\mathrm{MgO}$ content}

Figure 6 shows the effect of the $\mathrm{MgO}$ content of powders heat-treated at $1200^{\circ} \mathrm{C}$ on densification at $1600^{\circ} \mathrm{C}$. Those green compacts were embedded in as-produced powders $\mathrm{A}, \mathrm{B}$, and $\mathrm{C}$, respectively, and sintered for $2 \mathrm{~h}$. The relative density apparently decreased with the increasing $\mathrm{MgO}$

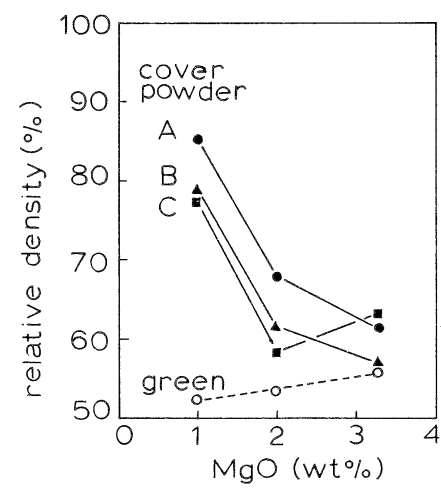

Fig. 6. Effect of $\mathrm{MgO}$ content of the powders calcined at $1200^{\circ} \mathrm{C}$ on the densification at $1600^{\circ} \mathrm{C}$. Green compacts were covered with the as-produced powders $\mathrm{A}, \mathrm{B}$ and $\mathrm{C}$ respectively in a $\mathrm{Pt}$ container and sintered for $2 \mathrm{~h}$. content of the heat-treated powders. In the sintered samples from powders of $2.0 \mathrm{wt} \% \mathrm{MgO}$ covered with powders $\mathrm{B}$ and $\mathrm{C}$, and in the sintered samples from powder of $3.3 \mathrm{wt} \% \mathrm{MgO}$ covered with powder $\mathrm{C}, \alpha$-alumina formed in addition to $\beta$-alumina. The lower sinterability of $\beta$-alumina powders with high $\mathrm{MgO}$ content was also reported by Kennedy and Sammells. ${ }^{29)}$ The higher green density with higher $\mathrm{MgO}$ content can be explained by powder packing in the bimodal particle-size system, which suggests the homogeneous distribution of fine particles in the spaces among the larger platelike $\beta$-alumina particles. ${ }^{30)-32 \text { ) }}$

Figure 6 also represents the influence of the chemical composition of the as-produced powders covering the green compacts. Higher sintered density was achieved with cover powder A than with powder $\mathrm{B}$ or $\mathrm{C}$. This result is related to the partial pressure of the $\mathrm{NaO}$ gas released from the cover powder during sintering in the $\mathrm{Pt}$ container. As-produced powder A lost more $\mathrm{Na}_{2} \mathrm{O}$ with heating than did $\mathrm{B}$ or $\mathrm{C}$. This $\mathrm{Na}_{2} \mathrm{O}$-rich atmosphere suppressed the evaporation of $\mathrm{Na}_{2} \mathrm{O}$ from the green compacts during sintering and increased the densification rate; producing the $\mathrm{Na}_{2} \mathrm{O}$-rich atmosphere is thus very important to the sintering of $\beta$-alumina. Similar results were also reported by Francis et al. ${ }^{33}$ )

Figure 7 summarizes the $\mathrm{Na}_{2} \mathrm{O}: \mathrm{Al}_{2} \mathrm{O}_{3}$ ratio of the sintered samples as a function of relative density. Figure 6 shows that green compacts of $\beta$-alumina powders with lower $\mathrm{MgO}$ content reached higher density in an $\mathrm{Na}_{2} \mathrm{O}$-rich atmosphere, and that the evaporation of $\mathrm{Na}_{2} \mathrm{O}$ from the compacts during sintering was suppressed by increasing the partial pressure of $\mathrm{NaO}$ gas in the $\mathrm{Pt}$ container. These conclusions allow the following interpretation of Fig. 7. Since the lowdensity porous compact has a high surface area, its $\mathrm{Na}_{2} \mathrm{O}: \mathrm{Al}_{2} \mathrm{O}_{3}$ ratio would decrease during sintering because of greater $\mathrm{Na}_{2} \mathrm{O}$ loss by evapor-

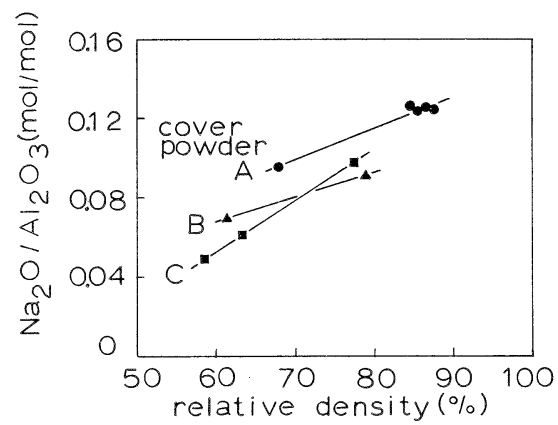

Fig. 7. Relation between chemical compositions and densities of samples sintered at $1600^{\circ} \mathrm{C}$. 
ation. The amount of $\mathrm{Na}_{2} \mathrm{O}$ lost from the compacts of course depends on the partial pressure of $\mathrm{NaO}$ in the atmosphere. The molar ratio of $\mathrm{Na}_{2} \mathrm{O}$ $: \mathrm{Al}_{2} \mathrm{O}_{3}$ for the samples thus increased with higher relative density.

\subsection{Chemical compositions and phases of the sintered samples}

The relation between chemical composition and phase was studied mainly for the samples sintered at $1600^{\circ} \mathrm{C}$. Loss of $\mathrm{Na}_{2} \mathrm{O}$ from the powder compacts occurred mostly with short sintering time $\left(<10 \mathrm{~min}\right.$ at $\left.1600^{\circ} \mathrm{C}\right)$ or during heating to sintering temperature. The vapor pressure of $\mathrm{NaO}$ gas thus should reach equilibrium within a relatively short time in the covered $\mathrm{Pt}$ container

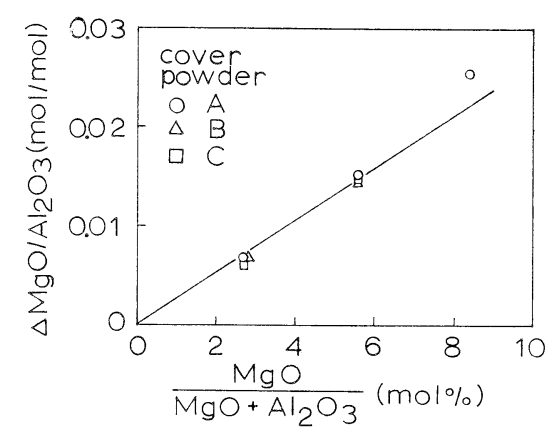

Fig. 8. $\mathrm{Mol} \%$ of $\mathrm{MgO}$ in the $\mathrm{MgO}-\mathrm{Al}_{2} \mathrm{O}_{3}$ system of asproduced powders and amount of $\mathrm{MgO}$ lost during sintering at $1600^{\circ} \mathrm{C}$ for $2 \mathrm{~h}$.

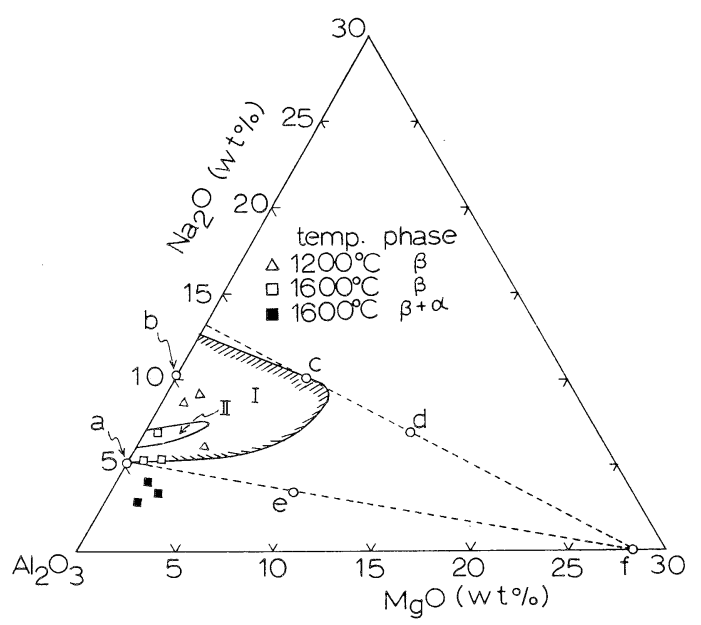

Fig. 9. Chemical compositions and phases of compacts sintered at $1600^{\circ} \mathrm{C}$ and powders heat-treated at $1200^{\circ} \mathrm{C}$. Region I and II illustrate the formation region of $\beta$-alumina from alkoxides at $1400^{\circ} \mathrm{C}^{25)}$ and by solid state reaction at $1700^{\circ} \mathrm{C},{ }^{34)}$ respectively. The compositions $\mathrm{a}, \mathrm{b}, \mathrm{c}, \mathrm{d}$, e and $\mathrm{f}$ correspond to $\beta$-alumina $\left(\mathrm{Na}_{2} \mathrm{O}\right.$. $\left.11 \mathrm{Al}_{2} \mathrm{O}_{3}\right), \quad \beta^{\prime \prime}$-alumina without $\mathrm{MgO}\left(\mathrm{Na}_{2} \mathrm{O} \cdot 5.33\right.$ $\left.\mathrm{Al}_{2} \mathrm{O}_{3}\right), \quad \beta^{\prime \prime}$-alumina with $\mathrm{MgO}\left(\mathrm{Na}_{2} \mathrm{O} \cdot \mathrm{MgO} \cdot 5 \mathrm{Al}_{2} \mathrm{O}_{3}\right)$, $\beta^{\prime \prime \prime \prime}$-alumina $\left(\mathrm{Na}_{2} \mathrm{O} \cdot 3 \mathrm{MgO} \cdot 7 \mathrm{Al}_{2} \mathrm{O}_{3}\right), \beta^{\prime \prime \prime}-\mathrm{Al}_{2} \mathrm{O}_{3}\left(\mathrm{Na}_{2} \mathrm{O} \cdot 4\right.$ $\left.\mathrm{MgO} \cdot 15 \mathrm{Al}_{2} \mathrm{O}_{3}\right)$ and spinel $\left(\mathrm{MgO} \cdot \mathrm{Al}_{2} \mathrm{O}_{3}\right)$, respectively. containing the green compacts and cover powders; that is, the covered $\mathrm{Pt}$ container should be a semi-closed system. Evaporation of $\mathrm{MgO}$ from the compacts was also detected, increasing with sintering time. Figure 8 shows the amount of $\mathrm{MgO}$ lost after sintering at $1600^{\circ} \mathrm{C}$ for $2 \mathrm{~h}$ as a function of $\mathrm{mol} \%$ of $\mathrm{MgO}$ in the system $\mathrm{MgO}$ $\mathrm{Al}_{2} \mathrm{O}_{3}$ for the as-produced powders. The high linearity in Fig. 8 suggests Henry's law concerning the evaporation of $\mathrm{MgO}$. The chemical composition of the cover powder had little effect on $\mathrm{MgO}$ evaporation.

Figure 9 summarizes the relation of chemical composition and phase for compacts sintered at $1600^{\circ} \mathrm{C}$ for $2 \mathrm{~h}$ and powders heat-treated at $1200^{\circ} \mathrm{C}$ for $3 \mathrm{~h}$ and shows the formation region for $\beta$ alumina from alkoxides at $1400^{\circ} \mathrm{C}$ as postulated by Ritter and Frase. ${ }^{25)}$ The present study showed a good agreement with previous studies for X-ray diffraction analysis. The $\beta$-alumina region in Fig. 9 is located inside the triangle represented by dashed lines, based on the spinel block structure. The formation of $\beta$-alumina by solid state reaction at $1700^{\circ} \mathrm{C}$ is also presented. ${ }^{34)} \mathrm{A}$ comparison of both reactions indicates that the hydrolysis of mixed alkoxides yields a larger formation of $\beta$-alumina.

\section{Discussion}

The relation between phase and chemical composition of samples in the system $\mathrm{Na}_{2} \mathrm{O}$ $\mathrm{MgO}-\mathrm{Al}_{2} \mathrm{O}_{3}$ heated at $1100^{\circ}$ to $1600^{\circ} \mathrm{C}$ was analy-

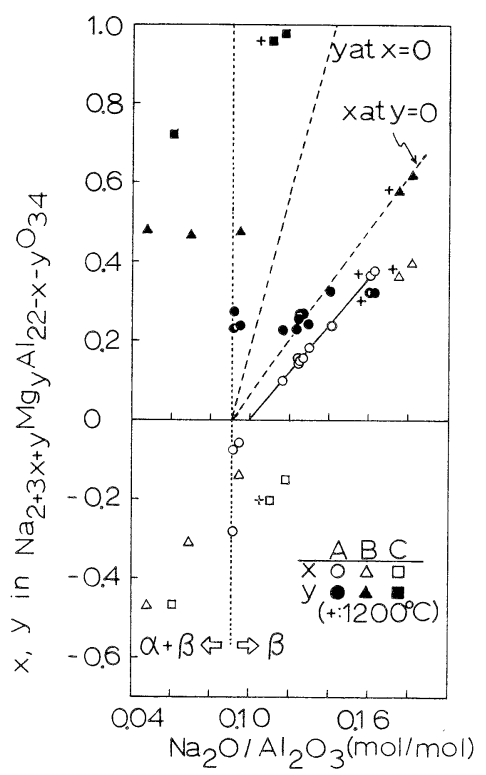

Fig. 10. $\mathrm{Na}_{2} \mathrm{O} / \mathrm{Al}_{2} \mathrm{O}_{3}$ ratio dependence of concentration of Al vacancy $(x)$ and substituted amount of $\mathrm{Mg}$ for $\mathrm{Al}(y)$ in the assummed equation of $\beta$-alumina solid solution, $\mathrm{Na}_{2+3 x+y} \mathrm{Mg}_{y} \mathrm{Al}_{22-x-y} \mathrm{O}_{34}$. 
zed assuming the $\beta$-alumina solid solution formula $\mathrm{Na}_{2+3 x+y} \mathrm{Mg}_{y} \mathrm{Al}_{22-x-y} \mathrm{O}_{34}$, where $x$ and $y$ indicate the concentration of $\mathrm{Al}$ vacancies and the amount of $\mathrm{Mg}$ substituted for $\mathrm{Al}$ in the spinel block of $\beta$-alumina, respectively. This solid solution equation gives the composition of ideal $\beta$-alumina $\mathrm{Na}_{2} \mathrm{O} \cdot 11 \mathrm{Al}_{2} \mathrm{O}_{3}$ for $x=y=0$, ideal $\beta^{\prime \prime}$ alumina $\mathrm{Na}_{2} \mathrm{O} \cdot 5.33 \mathrm{Al}_{2} \mathrm{O}_{3}$ for $x=0.667$ and $y=0$, and ideal $\mathrm{MgO}$-doped $\beta^{\prime \prime}$-alumina $\mathrm{Na}_{2} \mathrm{O} \cdot \mathrm{MgO}$. $5 \mathrm{Al}_{2} \mathrm{O}_{3}$ for $x=0$ and $y=2 .{ }^{35)}$ Figure 10 shows the values $x$ and $y$ calculated from the chemical compositions of heat-treated powders and sintered samples, as a function of the molar ratio of $\mathrm{Na}_{2} \mathrm{O}$ to $\mathrm{Al}_{2} \mathrm{O}_{3}$. Alpha alumina was not identified by $\mathrm{X}$-ray diffraction above the value of 0.0909 for the $\mathrm{Na}_{2} \mathrm{O}: \mathrm{Al}_{2} \mathrm{O}_{3}$ ratio for ideal $\beta$-alumina. The minus sign before the $x$ represents the precipitation of excess $\mathrm{MgO}$ above the solubility limit at $x$ $=0$ in the solid solution equation. This excess $\mathrm{MgO}$ may form an $\mathrm{MgO} \cdot \mathrm{Al}_{2} \mathrm{O}_{3}$ spinel, especially in the samples with an $\mathrm{Na}_{2} \mathrm{O}: \mathrm{Al}_{2} \mathrm{O}_{3}$ ratio lower than $0.0909 .{ }^{36)},{ }^{37)} \mathrm{No} \mathrm{MgO}$ or $\mathrm{MgO} \cdot \mathrm{Al}_{2} \mathrm{O}_{3}$ was detected by $\mathrm{X}$-ray diffraction when $\mathrm{MgO}$ content was low $(0.8$ to $3.3 \mathrm{wt} \%)$ in the heat-treated powders or the sintered samples.

Figure 10 also suggests the linear relation between the $\mathrm{Na}_{2} \mathrm{O}: \mathrm{Al}_{2} \mathrm{O}_{3}$ ratio and the $\mathrm{Al}$ vacancy concentration. Extrapolation of $x$ to 0 along the line for the powder $\mathrm{A}$ indicates the chemical composition $\mathrm{Na}_{2} \mathrm{O} \cdot 0.167 \mathrm{MgO} \cdot 10.0 \mathrm{Al}_{2} \mathrm{O}_{3}$, which contains no $\mathrm{Al}$ vacancy and $\sim 0.6 \mathrm{wt} \% \mathrm{MgO}$. Figure 10 could be used to evaluate the structural stability of $\beta$-alumina against $\mathrm{Na}_{2} \mathrm{O}$ loss during sintering. The $\mathrm{MgO}$-rich $\beta$-alumina would dissociate $\mathrm{MgO}$ more easily, by small $\mathrm{Na}_{2} \mathrm{O}$ loss, than the $\mathrm{MgO}$-poor $\beta$-alumina with the same $\mathrm{Na}_{2} \mathrm{O}$ $: \mathrm{Al}_{2} \mathrm{O}_{3}$ ratio. The $\mathrm{MgO}$-poor $\beta$-alumina with high $\mathrm{Na}_{2} \mathrm{O}$ content has a high structural stability against $\mathrm{Na}_{2} \mathrm{O}$ loss that is controlled by its $\mathrm{Al}$

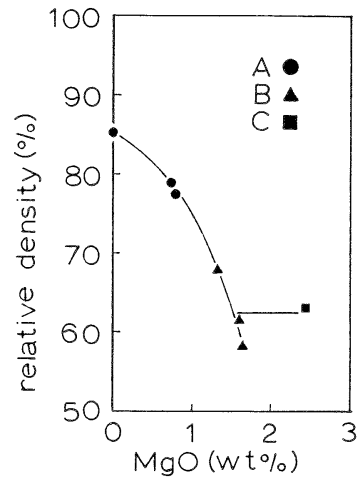

Fig. 11. Densities of samples sintered at $1600^{\circ} \mathrm{C}$ for $2 \mathrm{~h}$ as a function of calculated amount of excess $\mathrm{MgO}$ above the solubility limit in $\mathrm{MgO}$-doped $\beta$-alumina solid solution. vacancy concentration.

Figure 11 illustrates the densities of samples sintered at $1600^{\circ} \mathrm{C}$ for $2 \mathrm{~h}$ as a function of the calculated amount of excess $\mathrm{MgO}$ above the solubility limit $(x=0)$. The plotted data suggest that densification of $\beta$-alumina is inhibited by $\mathrm{MgO}$, which cannot dissolve into the $\beta$-alumina during sintering. The excess $\mathrm{MgO}$ could be decreased by suppressing $\mathrm{Na}_{2} \mathrm{O}$ loss from the compacts during sintering (Figs. 6 and 10); that is, an $\mathrm{Na}_{2} \mathrm{O}$-rich atmosphere is needed to prevent the loss of $\mathrm{Na}_{2} \mathrm{O}$ and the precipitation of $\mathrm{MgO}$ from $\beta$-alumina. Some of the $\mathrm{MgO}$ evaporates during sintering, but the evaporation rate of the $\mathrm{MgO}$ is lower than that of the $\mathrm{Na}_{2} \mathrm{O}$ or the rate for the dissociation of $\mathrm{MgO}$ from the $\beta$-alumina. As a result, the $\mathrm{MgO}$ remaining in the compacts decreases the densification rate. Alpha alumina that forms in the samples by $\mathrm{Na}_{2} \mathrm{O}$ evaporation would also inhibit $\beta$-alumina densification.

\section{Summary and conclusions}

Alkoxide-derived amorphous powder with the composition $\mathrm{Na}_{2} \mathrm{O} \cdot 0.163 \mathrm{MgO} \cdot 5.84 \mathrm{Al}_{2} \mathrm{O}_{3} \quad(\sim$ 1 wt $\% \mathrm{MgO}$ ) changed to platelike single crystals of $\beta$-alumina with an average size of $0.3 \mu \mathrm{m}$ at $1100^{\circ} \mathrm{C}$ through $\gamma$-alumina and mullite-type alumina phases. No change was observed in the shape and size of $\beta$-alumina particles during heat treatment at $1100^{\circ}$ to $1400^{\circ} \mathrm{C}$ for $3 \mathrm{~h}$. The particle size of the $\beta$-alumina increased with increasing $\mathrm{MgO}$ content. No $\beta^{\prime \prime}$-alumina formed in the system $\mathrm{Na}_{2} \mathrm{O}-\mathrm{MgO}-\mathrm{Al}_{2} \mathrm{O}_{3}$ from alkoxides, in contrast to the solid state reaction. The higher partial pressure of $\mathrm{NaO}$ gas in the sintering atmosphere effectively increased the density of sintered sample. In an $\mathrm{Na}_{2} \mathrm{O}$-poor atmosphere, $\mathrm{Na}_{2} \mathrm{O}$ evaporation from the compacts caused the precipitation of $\mathrm{MgO}$ and $\mathrm{Al}_{2} \mathrm{O}_{3}$ from the $\beta$-alumina. This precipitation of second phases in the $\beta$-alumina compacts inhibited densification. Evaporation of $\mathrm{MgO}$ from the compacts was also measured at a sintering temperature of $1600^{\circ} \mathrm{C}$. The amount of lost $\mathrm{MgO}$ followed Henry's law in the $\mathrm{MgO}-\mathrm{Al}_{2} \mathrm{O}_{3}$ system of $\beta$-alumina. The particle shape of the $\beta$-alumina plays an important role in the densification behavior during sintering. Aggregation of platelike particles caused a tendency toward the formation of pores surrounded by flat planes in the green compacts; pores of this type remained in the sintered samples. Control of both the shape of the starting particles and powder packing in the green compacts is important to producing a fully dense $\beta$-alumina body at low sintering temperature. ${ }^{38)}$ 
Acknowledgments The authors thank, Y. Kamino, T. Kokusho and T. Sonoda of Kagoshima Prefectural Institute of Industrial Technology for the chemical analysis of $\beta$-alumina.

\section{References}

1) K.S. Mazdiyasni, Ceramics International, 8, 42-56 (1982).

2) J-H. Jean and T. A. Ring, Am. Ceram. Soc, Bull., 65, 1574-77 (1986).

3) H. Okamura, E. A. Barringer and H. K. Bowen, J. Am. Ceram. Soc, 69, C22-C24 (1986).

4) L.H. Edelson and A. M. Glaeser, J. Am. Ceram. Soc, 71, 225-35 (1988).

5) S.S. Jada, J. Am. Ceram. Soc., 70, C 298- C 300 (1987).

6) J.C. Debsikdar, Adv. Ceram. Mater., 1, 93-98 (1988).

7) J-Y. Chane-Ching and L. C. Klein, J. Am. Ceram.Soc., 71, 83-85 (1988).

8) B.E. Yoldas, J. Mater. Sci., 21, 1087-92 (1986).

9) B. Fegley, Jr., P. White and H.K. Bowen, Am. Ceram. Soc. Bull., 64, 1115-20 (1985).

10) S. Hirano and K. Kato, Adv. Ceram. Mater., 2, 142-45 (1987).

11) M. Machida, K. Eguchi and H. Arai, J. Am. Ceram. Soc. , 71, 1142-47 (1988)

12) M. S. Whittingham and R. A. Huggins, J. Chem. Phys., 54, 414-16 (1971)

13) Y-F. Yu Yao and J. T. Kummer, J. Inorg. Nucl. Chem., 29, 2453-75 (1967).

14) G. C. Farrington and J. L. Briant, "Ionic Conductivity in Beta" Alumina", in Fast Ion Transport in Solids, Eds., P. Vashishta, J. N. Mundy and G. K. Shenoy, Elsevier North Holland, Inc. (1979) pp. 395-400.

15) H. Sato and R. Kikuchi, J. Chem. Phys., 55, 677-702 (1971).

16) R.W. Powers, Am. Ceram. Soc. Bull., 65, 1270-77 (1986).

17) R. O. Ansell, J. Mater. Sci., 21, 365-79 (1986).

18) R. N. Singh, J. Am. Ceram. Soc, , 70, 221-26 (1986).

19) J.A. Smaga and J.E. Battles, J. Mater. Sci. Lett., 4, 553-57 (1985).

20) T. Y. Tseng, H. M. Tsai and T. M. Uen, J. Mater. Sci. Lett. , 5, 433-35 (1986).

21) B. E. Yoldas and D. P. Partlow, Am. Ceram. Soc.
Bull. , 59, 640-42 (1980).

22) A. G. Elliot and R. A. Huggins, J. Am. Ceram. Soc., 58, 497-500 (1975).

23) A. J. Perrotta and J.E. Young, Jr., J. Am. Ceram. Soc, , 57, 405-07 (1974).

24) J. D. Hodge, Am. Ceram. Soc. Bull. , 62, 244-48 (1983).

25) J. J. Ritter and K. G. Frase, "Low-Temperature Synthesis of Ceramic Powders for Structural and Electronic Applications", in Science of Ceramic Chemical Processing, Eds., L. L. Hench and D. R. Ulrich, John Wiley \& Sons, Inc. (1986) pp. 497-503.

26) C. R. Peters, M. Bettman, J.W. Moore and M.D. Glick, Acta Cryst, B27, 1826-34 (1971).

27) N. J. Dudney and J. B. Bates, J. Am. Ceram. Soc ., 70, 816-21 (1987).

28) J.B. Bates, D. Dohy and R. L. Anderson, J. Mater. Sci. , 20, 3219-29 (1985).

29) J.H. Kennedy and A.F. Sammells, J. Electrochem. Soc., 119, 1609-13 (1972).

30) C. Han, I. A. Aksay and O.J. Whittmore, "Characterization of Microstructural Evolution of Mercury Porosimetry", in Advances in Materials Characterization II, Eds., R. L. Snyder, R. A Condrate, Sr. and P.F. Johnson, Plenum Publ. Co. (1985) pp. 339-47.

31) Y. Hirata and I. A. Aksay, "Particle Segregation during Colloidal Filtration", Proceedings of the International Workshop for Advanced Materials Technology, Ceramics IN, Japan Fine Ceramics Center, 1988, in press.

32) J. V. Milewski, Adv. Ceram. Mater., 1, 36-41 (1986).

33) T. L. Francis, F.E. Phelps and G. Maczura, Am. Ceram. Soc. Bull., 50, 615-19 (1971).

34) J. T. Kummer, Prog. Solid State Chem., 7, 141-75 (1972).

35) M. Bettman and C.R. Peters, J. Phys. Chem., 73, 1774-80 (1969).

36) A. Imai and M. Harata, J. J. Appl. Phys., 11, 180-85 (1972)

37) S. Kihara, K. Koumoto, Y. Nishikawa and H. Yanagida, Yogyo-Kyokai-Shi, 88, 427-29 (1980).

38) A. Kato and $Y$. Hirata, The Memoirs of the Faculty of Engineering, Kyushu University, 45, No.4, 251-71 (1985). 